\title{
Parent partnership and 'quality' early years services: practitioners' perspectives
}

\author{
Michelle Cottle ${ }^{1}$ and Elise Alexander
}

School of Education, University of Roehampton, London, United Kingdom

\begin{abstract}
This article begins by outlining the historical and political context of 'parent partnership' within the UK. It locates the perspectives of early years' practitioners within this context, drawing on data from an Economic and Social Research Council (ESRC)-funded study of eighteen English early years settings, including interviews and focus groups with 165 practitioners in a variety of roles. The findings reveal that, although all practitioners considered parent partnership to be an essential element in quality early years services, the partnerships themselves were understood and enacted in very different ways. Practitioners appear to be influenced by dominant policy discourses as well as their personal and professional histories and their perceptions of the purposes and priorities of their setting. In discussing the nature of 'parent partnership', we focus on tensions inherent in English policy discourses, reflecting on the previous Labour government policy as well as changes introduced by the current Coalition government.
\end{abstract}

RÉSUMÉ: Cet article commence par décrire le contexte historique et politique de «partenariat parent» au sein du Royaume-Uni. Il localise les points de vue des praticiens des premières années au sein de ce contexte, en s'appuyant sur les données d'une recherche économique et sociale (ESRC) financé par l'étude de dix-huit premières années anglais paramètres, y compris des entrevues et des groupes de discussion avec 165 praticiens dans une variété de rôles. Les résultats révèlent que, bien que tous les praticiens considérés comme partenariat entre les parents est un élément essentiel dans la qualité des services à la petite enfance, les partenariats eux-mêmes ont été compris et adopté de manière très différente. Les praticiens semblent être influencés par les discours politiques dominants,

\footnotetext{
${ }^{1}$ Corresponding author email: $\underline{\text { m.cottle@ } @ \text { roehampton.ac.uk }}$
} 
ainsi que leurs histoires personnelles et professionnelles et leurs perceptions des buts et des priorités de leur milieu. En analysant la nature de «partenariat parent», nous nous concentrons sur les tensions inhérentes dans les discours politiques anglais, en réfléchissant sur la politique précédent gouvernement travailliste ainsi que les changements introduits par le gouvernement de coalition actuel.

ZUSAMMENFASSUNG: Dieser Artikel wird zunächst auf die historischen und politischen Kontext von "Eltern Partnerschaft" innerhalb des Vereinigten Königreichs. Es lokalisiert die Perspektiven der frühen Jahre "Praktiker in diesem Zusammenhang, gestützt auf Daten aus einem Economic and Social Research Council (ESRC) geförderten Studie von achtzehn jungen Jahren EnglischEinstellungen, einschließlich Interviews und Fokusgruppen mit 165Praktizierenden in einer Vielzahl von Rollen. Die Ergebnisse zeigen, dass, obwohl alle Praktiker als Elternteil Partnerschaft auf ein wesentliches Element in der Qualität frühen Jahren Dienstleistungen sein, die Partnerschaften selbst verstanden wurden und erließ auf sehr unterschiedliche Weise. Praktiker scheinen durch die vorherrschenden politischen Diskurse sowie ihre persönliche und berufliche Geschichte und ihre Wahrnehmungen von den Zielen und Prioritäten ihrer Einstellung beeinflusst werden. Bei der Erörterung der Natur des "Eltern Partnerschaft" haben wir auf innewohnenden Spannungen in der englischen Politik Diskurse konzentrieren, was auf der vorherigen Labour-Politik der Regierung sowie die Veränderungen durch die derzeitige Koalition eingeführt.

RESUMEN: Este artículo comienza por describir el contexto histórico y político de la "asociación los padres en el Reino Unido. Se localiza los puntos de vista de los profesionales de educación inicial dentro de este contexto, sobre la base de datos de una investigación del Consejo Económico y Social (CERS), financiado por el estudio de la configuración de dieciocho primeros años de inglés, incluyendo entrevistas y grupos focales con 165 profesionales en una variedad de papeles. Los resultados revelan que, a pesar de todos los profesionales de la asociación considera los padres a ser un elemento esencial en la calidad de los servicios de los primeros años, las propias asociaciones se entiende y se promulgó en formas muy diferentes. Los médicos parecen estar influenciados por los discursos políticos dominantes, así como sus historias personales y profesionales y sus percepciones sobre los propósitos y prioridades de su entorno. Al discutir la naturaleza de la "sociedad matriz", nos centramos en las tensiones inherentes en los discursos políticos en inglés, lo que refleja en la política laboral 
del gobierno anterior, así como los cambios introducidos por el actual gobierno de coalición.

Keywords: parent partnership; practitioners' perspectives; England; early years; quality

\section{Introduction}

This article draws on data from a recent ESRC-funded research project (RES-061-230012) which examined practitioners' understandings of 'quality' and 'success' in a range of English early years settings and schools. The value of parent partnership was strongly endorsed by the practitioners involved in our study, who saw good partnerships as an indicator of quality. However, the partnerships themselves were understood and enacted in very different ways. We infer that these differences are rooted in practitioners' constructions of parents and that these in turn are influenced by practitioners' personal and professional histories (Goodson, 2003), their perceptions of the purposes and priorities of their setting and the national policy context. This article highlights the difficulty of defining concepts relating to parental involvement in both policy and practice (Crozier \& Reay, 2005; Hujala et al 2010) and the tensions inherent in policy discourses which tend to oversimplify highly complex relationships (Blackmore \& Hutchison, 2010). We start with a brief examination of the historical context relating to parent-practitioner relationships in the early years, before moving on to review the ways in which policy has developed over the past thirty years. We focus particularly on the context in which the fieldwork was carried out before considering the potential impact of more recent policy developments on both practitioners and parents in our conclusion. Our analysis examines the centrality of discourses of deficiency and agency, also highlighting an 'official' approach to children's learning (Tanner et al. 2006) that subjugates it to the Government 'quality' agenda. We highlight the ways that this context has influenced practitioners and parents with reference to recent research 
evidence from different early years contexts. The discussion of our own findings locates and explores early years practitioners' perspectives on parent partnerships within these debates.

\section{The historical and political origins of 'partnership'}

There is a tradition of practitioners working closely with the parents of young children in England (Pugh \& Duffy, 2006; Fitzgerald 2004; Whalley 1997) and practitioners can play a central role in helping children and parents to develop the skills and attitudes to successfully manage transition and change (Robson, 2006). But there are a number of other, often contradictory reasons for parent partnership, both historically and politically. Some of these relate to the origins of different types of early childhood settings in the 19th century when nurseries and voluntary organisations provided care for the children of poorer working families and schools or kindergartens provided parttime education for the children of middle-class families (Moss 2004). Aspects of contemporary understandings of parent partnership are rooted in a compensatory model which dates back to these nursery school origins. For example Margaret Macmillan was one of the first nursery education pioneers to emphasise the importance of parental involvement but her approach called attention to the deficits of the home environment and her own 'expert' status through a parent education programme (Steedman, 1990). This model remains influential, as we discuss below, and Smidt (2007) argues that parents have frequently been perceived as 'good' or 'bad' depending on their visibility within settings and the ways that they support what happens there.

Over the 20th century, the divide between education and care became more distinct as provision for young children was largely excluded from the development of the national education system and educational policy. Throughout the 1970s and 80s, perceptions of parents became more complex, based in part upon growing research 
evidence of the positive impact of parental involvement upon a child's development at home as well as within the setting (for example, Tizard \& Hughes, 1984). But although this research acknowledged parents' expertise and encouraged a view of parents as 'partners' in learning, the discourse of deficiency prevailed in much other research which was often based on intervention programmes compensating for children's perceived inadequacies upon entering school (Muschamp et al., 2010). Around the same time, discourses of agency were starting to emerge as Conservative Government policies re-positioned parents as 'consumers' and drivers of excellence in line with their market ideology so began the era of active parental involvement in the education process (Alexander, 2009, Crozier, 2000, Muschamp et al., 2010).

\section{The policy context of the 'Quality and Success' project}

The advent of the New Labour Government in 1997 raised expectations of change due to their communitarian traditions (Wright 2011). The concept of 'parent partnership' was developed into a key ingredient of their quality agenda, in line with European policy (Eurydice Report, 2009 186). But, despite a shift in rhetoric from parent-asconsumer to parent-as-partner (DfEE, 1997, DfES 2003a, DfES, 2007), there were strong continuities in terms of market ideology and deficit models of parenting, in educational policy (Muschamp et al., 2010).

A significant number of initiatives reformed the organisation, administration and management of schools by encouraging more parental participation (Desforges \& Abouchaar, 2003). Indeed it can be argued that parent partnership was becoming a form of surveillance (Crozier 1998) extending the notion of deficit to incorporate the teachers as well as parents. Edwards and Warin (1999) argue that subject knowledge had become a political commodity following the introduction of the National Curriculum in 1988. They view this as an attempt to homogenise British society with 
parental involvement policies encouraging the 'colonisation of the home by school' (1999 337). The 'scholarisation' of the home continues to be an issue, there are concerns that this may alienate parents and children and undervalue the 'funds of knowledge' embedded in the particular cultures of homes and communities (Alexander, 2009 87). However the overall picture appears mixed. Some schools feel partnership is about recruiting parents to their purposes or ensuring the smooth operation of bureaucratic procedures, in line with market ideology, but to others it represents a genuine opportunity to share decisions about children with parents (Barron et al., 2010).

The above policies are likely to have influenced the relationships between early years practitioners and parents yet they relate largely to school-based settings which is only part of the early years picture in England. New Labour was working towards a vision of integrated education and care (DfES 2003a), introducing legislation that focused on early years provision across different types of setting (DfEE/QCA, 2000; DfES, 2002; DCSF, 2007a). Despite an emphasis on promoting diversity in principle, the practical guidance encourages parents to contribute to their child's learning in very specific ways, both in the setting and at home, with practitioners cast as role models. It is also important to highlight the conflicting messages within these documents regarding the ways that young children learn. On the one hand, legal requirements relating to children's welfare and learning emphasise age-related developmental phases and a series of learning goals that all children should attain by the age of five (DCSF, 2007c) and, on the other, non-statutory guidance establishes principles of practice based upon children's choices and play interests (DCSF, 2007b). The distinction between attainment and the process of learning is not in itself contradictory, the issue is one of interpretation. But the statutory emphasis gives an indication of the type of learning 
that is prioritised in 'official' Government discourses (Tanner et al. 2006) which will of course be influential as it is linked to accountability.

At least two contradictory discourses can be identified here. One revolves around parent agency and another around notions of deficient parenting (Blackmore \& Hutchison, 2010). These indicate both the influence of the historical context and ideological contradictions within New Labour policies. There have long been tensions between commitments to quality control and standardisation, emphasising the market ideology inherited from the previous Conservative Government, and the perhaps more traditional Labour values of social justice, democracy and diversity (Brain \& Reid, 2003, Gewirtz, 2000) and these are reflected in the early years legislation above. As a result, despite the stated New Labour aim to 'tackle poverty' (Baldock et al., 2009), parents continued to foot most of the cost of care and education of their young children throughout their terms of government with some intervention for lower income families (Pugh, 2010). Policy has tended to treat parents as a homogenous group, or perhaps two homogenous groups as indicated above, with little account of gender, social class and ethnic differences (Crozier \& Reay, 2005) and, in this way, parental involvement has become a 'lever to maximise the potential of the already advantaged'(Hallgarten, 2000 18). However, there is evidence that consideration of class and ethnicity are central to the formation of effective, trusting partnerships between practitioners and parents. While the well-being of the child is central to the partnership between parents and practitioners, the relationships between them, triangulated with relationships with the children, are crucial. Hohmann (2007) characterises this as the 'caring triangle'. She suggests that the expectations which underpin the relationships between parents and practitioners may have their origins in the kind of mothering experienced by both. Brooker (2010) argues further that class and cultural differences, as well as conflicting 
understandings of 'professionalism' inform the development of this triangle. As a result the combination of practitioner and parent expectations can either promote the formation of a trusting partnership, or become a 'breeding-ground for tension' (Hohmann 2007:33). It could also be argued that there is more potential for the colonisation of the home by educators in the early years because of greater scope for interaction due to the age of the children.

In addition, settings have been given the role of regenerating social capital in deprived areas, particularly through initiatives such as Sure Start (DfEE 1998) and the nation-wide adoption of the Sure Start Children's Centre model (HM Treasury 2004), which further complicates the relationship between home and setting. Blackmore and Hutchison (2010) argue that both parents and practitioners can feel ambivalent towards policies that fail to acknowledge the complexity of the relationship between them. There are multiple subject positions arising from different views and experiences as well as from material conditions and the 'economic, sociocultural and racialised relations' (2010 4) that inform them. Although the practitioners involved in our study all advocated the notion of parent partnership as an important element of quality provision, their comments demonstrated the complex nature of these relationships and the impact of these contradictory policy discourses.

\section{The study}

The overall study examined practitioners' perspectives on how the practitioners defined 'quality' and 'success' in the context of their particular setting. Data were collected from practitioners working in 18 early years settings: four schools, three nurseries and eleven Children's Centres (see Alexander, 2009; Alexander, 2010, Cottle \& Alexander 2012; Cottle 2011). Whilst not claiming that the sample was in any way representative, the selection of a range of socio-economic contexts, which included inner city, outer 
city, suburban and rural localities and inhabited by ethnically diverse communities, was intended to ensure that the analysis took account of the specificities of local contexts (see Table 2 below). The fieldwork was conducted over a 10 month period, beginning in May 2007 and ending in March 2008. A range of methods was used, following ESRC-approved ethical procedures. The purpose of the research was explained to all participants and their informed consent was obtained. The aim of the investigation was not to evaluate practitioners' ways of thinking about 'quality' but rather to investigate these and to consider the impact of existing constraints, assumptions and practices on their professional understandings. Because of the potential sensitivity of this investigation, particular care was taken to protect the identity of all participants and to anonymise the settings. Methods included: documentary analysis, observations and audio-recorded interviews and focus groups with practitioners working in a range of roles (see Table 1 below). The interviews and focus group discussions were designed to gather information about practitioners' personal and professional histories and values (supplemented by a biographical questionnaire), their understandings of the contexts of the settings (structure, aims and purposes) and their perspectives on 'quality' and 'success', which included an exploration of their ideals, aspirations, inspirations and constraints. Transcripts and questionnaire data were coded and analysed to identify emerging themes using the constant comparison method and then compared using a series of matrices in a process of cross-case analysis (Miles \& Huberman, 1994). The data were analysed using frameworks derived from studies of children's learning and Government documents (DCSF, 2007a, DfEE/QCA, 2000, Rumbold/DES, 1990, DfES, 2002, Isaacs 1932; Sylva et al., 2004) and a quality-defining continuum devised by Tanner at al. (2006). From these a series of analytic lenses was devised that allowed us to gain insights into practitioners' understandings of 'quality'. Maclure’s (2003) 
discussion of discourse analysis was also useful. We define 'discourses' as 'practices for producing meaning, forming subjects and regulating conduct within particular societies and institutions at particular historical times' (Maclure 2003: 175); thus a discourse is more than language, although language is crucial. This definition sits well with our symbolic interactionist framework which posits that social understandings and personal identities are generated through interaction with others (Schwandt 1998). As such, agentic and deficit discourses of parent partnership (Blackmore \& Hutchison, 2010, Feiler et al., 2006) and Epstein and Saunders' (2002) models of parent partnership have provided a another helpful frame for exploring practitioners' perceptions of parents and partnership.

Table 1: Practitioner roles

\begin{tabular}{|c|c|c|c|c|}
\hline Current role & \multicolumn{4}{|c|}{ Type of Setting } \\
\hline & 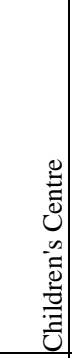 & 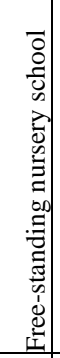 & 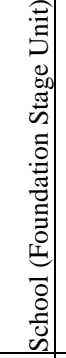 & $\begin{array}{l}\frac{n}{\pi} \\
\frac{\tilde{\sigma}}{\theta} \\
\end{array}$ \\
\hline Nursery Nurse / Officer & 37 & 7 & 3 & 47 \\
\hline Teacher & 27 & 5 & 12 & 44 \\
\hline Assistants & 10 & 6 & 13 & 29 \\
\hline Head / Manager & 11 & 3 & 4 & 18 \\
\hline Other senior roles* & 8 & 6 & 0 & 14 \\
\hline Early Years Educator** & 13 & 0 & 0 & 13 \\
\hline Totals & 106 & 27 & 32 & 165 \\
\hline
\end{tabular}

*'Other senior roles' does not include practitioners with a dual role (e.g. nursery nurse and senior role); in these cases practitioners selected their principal role.

**'Early Years Educator' was a universal title implemented in some of the Children's Centres as part of the restructuring of the setting. 
Table 2: Contextualised Information on Settings

\begin{tabular}{|c|c|c|c|c|c|c|c|c|}
\hline Pseudonym & Type & Location & $\begin{array}{l}\text { No. of years the } \\
\text { setting had been } \\
\text { established at time } \\
\text { fieldwork took place }\end{array}$ & $\begin{array}{l}\text { Number of } \\
\text { children } \\
\text { on roll }\end{array}$ & $\begin{array}{l}\text { Ofsted data: } \\
\text { eligibility for } \\
\text { free school } \\
\text { meals (FSM)* }\end{array}$ & $\begin{array}{l}\text { Ofsted data: } \\
\text { children learning } \\
\text { English as an } \\
\text { additional language } \\
\text { (EAL)** }\end{array}$ & Ofsted data: narrative descriptions of the setting & $\begin{array}{l}\text { Practitioners' descriptions of the setting users } \\
\text { (their terminology) }\end{array}$ \\
\hline Regent & $\begin{array}{l}\text { Children's } \\
\text { Centre }\end{array}$ & Inner city & $0-1$ & 46 & above average & above average & $\begin{array}{l}\text { Previously well-established nursery school serving } \\
\text { local population, range of ethnic/cultural backgrounds } \\
\text { from professional and lower income families }\end{array}$ & $\begin{array}{l}\text { Setting serves local population; mixture of } \\
\text { middle and working class families; a significant } \\
\text { number of EAL children }\end{array}$ \\
\hline Northfield & $\begin{array}{l}\text { Children's } \\
\text { Centre }\end{array}$ & $\begin{array}{l}\text { Outer } \\
\text { city }\end{array}$ & $0-1$ & 49 & above average & above average & $\begin{array}{l}\text { Previously well-established nursery school serving } \\
\text { local population, range of ethnic/cultural backgrounds } \\
\text { from professional and lower income families }\end{array}$ & $\begin{array}{l}\text { Setting serves local population. Generally } \\
\text { needy, vulnerable families, single parents but } \\
\text { also middle class. A significant number of EAL } \\
\text { children }\end{array}$ \\
\hline Rosewood & $\begin{array}{l}\text { Children's } \\
\text { Centre }\end{array}$ & $\begin{array}{l}\text { Outer } \\
\text { city }\end{array}$ & $1-3$ & 91 & No data & above average & $\begin{array}{l}\text { Previously well-established social services day centre, } \\
\text { serving local population, range of ethnic/cultural } \\
\text { backgrounds from professional and lower income } \\
\text { families }\end{array}$ & $\begin{array}{l}\text { Setting serves local population, mostly working } \\
\text { class and needy parents but some middle class, } \\
\text { single parents. There are a significant number } \\
\text { of EAL children. }\end{array}$ \\
\hline Queens & $\begin{array}{l}\text { Children's } \\
\text { Centre }\end{array}$ & $\begin{array}{l}\text { Outer } \\
\text { city }\end{array}$ & $1-3$ & 91 & No data & above average & $\begin{array}{l}\text { Previously well-established nursery school, nearly } \\
\text { half population are of White British heritage, small } \\
\text { number from minority backgrounds, although higher } \\
\text { than average percentage of EAL children, mixture of } \\
\text { professional and lower income families }\end{array}$ & $\begin{array}{l}\text { Setting serves local population, predominantly } \\
\text { middle class but increasing numbers of needy, } \\
\text { vulnerable, deprived families. Some EAL } \\
\text { children. }\end{array}$ \\
\hline Brackenridge & $\begin{array}{l}\text { Children's } \\
\text { Centre }\end{array}$ & Suburban & $1-3$ & 61 & below average & below average & $\begin{array}{l}\text { Previously well-established nursery school, serves } \\
\text { local population of mainly White British heritage, } \\
\text { small number from minority backgrounds, mainly } \\
\text { professional families }\end{array}$ & $\begin{array}{l}\text { Setting serves local population, mainly middle } \\
\text { class, reasonably affluent, professional parents } \\
\text { but some working class and a small number of } \\
\text { needy families. }\end{array}$ \\
\hline Emanuel & $\begin{array}{l}\text { Children's } \\
\text { Centre }\end{array}$ & Rural & $1-3$ & 119 & below average & above average & $\begin{array}{l}\text { Previously well-established nursery school and Early } \\
\text { Excellence Centre, serves local population of mainly } \\
\text { White British heritage, small number from minority } \\
\text { backgrounds, although higher than average } \\
\text { percentage of EAL children, mainly professional } \\
\text { families }\end{array}$ & $\begin{array}{l}\text { Setting serves local and wider population. } \\
\text { Mainly middle class but increasing numbers of } \\
\text { working class and 'hard to reach' families. A } \\
\text { significant number of EAL children. }\end{array}$ \\
\hline Lowood & $\begin{array}{l}\text { Children's } \\
\text { Centre }\end{array}$ & Rural & $1-3$ & 80 & No data & below average & $\begin{array}{l}\text { Previously well-established nursery school, serves } \\
\text { local population of mainly White British heritage, } \\
\text { small number from minority backgrounds, mainly } \\
\text { professional families }\end{array}$ & $\begin{array}{l}\text { Setting serves local population, mainly middle } \\
\text { class, professional. Some 'hard to reach' } \\
\text { families. Some EAL children. }\end{array}$ \\
\hline Chandlers & $\begin{array}{l}\text { Children's } \\
\text { Centre }\end{array}$ & Suburban & $1-3$ & 151 & above average & above average & $\begin{array}{l}\text { Previously Early Excellence Centre formed after } \\
\text { merger of several local nurseries, range of } \\
\text { ethnic/cultural backgrounds from professional and } \\
\text { lower income families }\end{array}$ & $\begin{array}{l}\text { Setting serves local population, mixture of } \\
\text { middle class or professional and working class } \\
\text { parents, 'hard to reach' families, single parents, } \\
\text { young parents with 'high social needs' . There } \\
\text { are a sign cant number of EAL children. }\end{array}$ \\
\hline Stockton & $\begin{array}{l}\text { Children's } \\
\text { Centre }\end{array}$ & Suburban & $1-3$ & 80 & No data & below average & $\begin{array}{l}\text { Serves local population of mainly White British } \\
\text { heritage, small number from minority backgrounds, } \\
\text { mixture of professional and lower income families }\end{array}$ & $\begin{array}{l}\text { Setting serves local population, mixture of } \\
\text { middle and working class, deprived families, } \\
\text { single and very young parents. High number of } \\
\text { family breakups. }\end{array}$ \\
\hline Churchill & $\begin{array}{l}\text { Children's } \\
\text { Centre }\end{array}$ & Inner city & $3-5$ & 144 & above average & above average & $\begin{array}{l}\text { Previously well-established social services day centre, } \\
\text { serving local population, range of ethnic/cultural } \\
\text { backgrounds from professional and lower income }\end{array}$ & $\begin{array}{l}\text { Setting serves local population, mixture of } \\
\text { middle and working class, single parents. There } \\
\text { are a sign cant number of EAL children. }\end{array}$ \\
\hline
\end{tabular}




\begin{tabular}{|c|c|c|c|c|c|c|c|c|}
\hline Pseudonym & Type & Location & $\begin{array}{l}\text { No. of years the } \\
\text { setting had been } \\
\text { established at time } \\
\text { fieldwork took place }\end{array}$ & $\begin{array}{l}\text { Number of } \\
\text { children } \\
\text { on roll }\end{array}$ & $\begin{array}{l}\text { Ofsted data: } \\
\text { eligibility for } \\
\text { free school } \\
\text { meals (FSM)* }\end{array}$ & $\begin{array}{l}\text { Ofsted data: } \\
\text { children learning } \\
\text { English as an } \\
\text { additional language } \\
\text { (EAL)** }\end{array}$ & Ofsted data: narrative descriptions of the setting & $\begin{array}{l}\text { Practitioners' descriptions of the setting users } \\
\text { (their terminology) }\end{array}$ \\
\hline & & & & & & & families & \\
\hline Vale & $\begin{array}{l}\text { Children's } \\
\text { Centre }\end{array}$ & Rural & $3-5$ & 103 & No data & average & $\begin{array}{l}\text { Serves local population of mainly White British } \\
\text { heritage, but significant proportion from minority } \\
\text { backgrounds, professional and lower income families }\end{array}$ & $\begin{array}{l}\text { Setting serves local population, needy, 'hard to } \\
\text { reach', also middle class, some single and very } \\
\text { young parents. There are a sign cant number of } \\
\text { EAL children. }\end{array}$ \\
\hline $\begin{array}{l}\text { Nesbit } \\
\text { Nursery }\end{array}$ & $\begin{array}{l}\text { Private Day } \\
\text { Nursery }\end{array}$ & Rural & $1-3$ & 147 & No data & No data & $\begin{array}{l}\text { New nursery set up to serve local population and } \\
\text { commuters who work in nearby city. Mainly White } \\
\text { British heritage, but significant proportion from } \\
\text { minority backgrounds, professional and lower income } \\
\text { families }\end{array}$ & $\begin{array}{l}\text { Setting serves mainly the local population, } \\
\text { mixture of middle and working class. There are } \\
\text { a sign cant number of EAL children. }\end{array}$ \\
\hline Trent & $\begin{array}{l}\text { Nursery } \\
\text { school }\end{array}$ & Inner city & over 10 & 85 & above average & above average & $\begin{array}{l}\text { Well-established nursery school serving local } \\
\text { population. Range of ethnic/cultural backgrounds } \\
\text { mainly from professional families. }\end{array}$ & $\begin{array}{l}\text { Setting serves the local population, mainly } \\
\text { working class. There are a sign cant number of } \\
\text { EAL children. }\end{array}$ \\
\hline Caroline & $\begin{array}{l}\text { Nursery } \\
\text { school }\end{array}$ & Rural & over 10 & 79 & below average & above average & $\begin{array}{l}\text { Well-established nursery school serving local and } \\
\text { wider population. Range of ethnic/cultural } \\
\text { backgrounds mainly from professional families. }\end{array}$ & $\begin{array}{l}\text { Setting serves mainly local population, mainly } \\
\text { middle but some working class, a few single and } \\
\text { very young parents. }\end{array}$ \\
\hline Edgehill & $\begin{array}{l}\text { Primary } \\
\text { school }\end{array}$ & $\begin{array}{l}\text { Outer } \\
\text { city }\end{array}$ & over 10 & 686 & No data & above average & $\begin{array}{l}\text { Large well-established primary school serving local } \\
\text { population. Range of ethnic/cultural backgrounds } \\
\text { mainly from professional families. }\end{array}$ & $\begin{array}{l}\text { Setting serves mainly local population, mainly } \\
\text { white middle class }\end{array}$ \\
\hline Downside & $\begin{array}{l}\text { Primary } \\
\text { school }\end{array}$ & Rural & over 10 & 229 & average & above average & $\begin{array}{l}\text { Well-established, average-sized primary school } \\
\text { serving local population. Range of ethnic/cultural } \\
\text { backgrounds, mixed from professional and lower } \\
\text { income families. }\end{array}$ & $\begin{array}{l}\text { Setting serves local population, mixture of } \\
\text { middle and working class, a significant number } \\
\text { of EAL children. }\end{array}$ \\
\hline Meadowview & $\begin{array}{l}\text { Primary } \\
\text { school }\end{array}$ & Suburban & over 10 & 198 & average & above average & $\begin{array}{l}\text { Well-established, average-sized primary school } \\
\text { serving local population. Range of ethnic/cultural } \\
\text { backgrounds, mixed from professional and lower } \\
\text { income families. }\end{array}$ & $\begin{array}{l}\text { Setting serves local and wider population, } \\
\text { mixture of middle and working class, a } \\
\text { significant number of EAL children. }\end{array}$ \\
\hline St Faith's & $\begin{array}{l}\text { Primary } \\
\text { school }\end{array}$ & Suburban & over 10 & 234 & below average & above average & $\begin{array}{l}\text { Well-established, average-sized primary school } \\
\text { serving local and wider population. Range of } \\
\text { ethnic/cultural backgrounds mainly from professional } \\
\text { families. }\end{array}$ & $\begin{array}{l}\text { Setting serves local and wider population, } \\
\text { mainly white middle class. There are some } \\
\text { EAL children. }\end{array}$ \\
\hline
\end{tabular}

Data from Ofsted on FSM, EAL and narrative descriptions are based on Ofsted reports current at the time of data collection (May 2007 - March 2008)

*National average for FSM in maintained nursery and primary schools in 2007: 15.9\% (figures were not provided where children did not eat on the premises)

**National average of EAL learners in primary schools in 2007: $13.5 \%$

(National average statistics are taken from DCSF (2008) Pupil Characteristics and Class Sizes in Maintained Schools in England: January 2008, Statistical First Release 09/2008.) 


\section{Practitioners' views on parent partnership in relation to 'quality'}

Parent partnership was invariably included as a central tenet in discussing quality services and the aims and goals of the setting. All practitioners espoused principles around respectful relationships and effective communication. They frequently described parents as the 'first educators', in keeping with both early years traditions (Isaacs 1932; Whalley 1997) and the curriculum guidance that was current at the time (DfEE/QCA, 2000). However, discussions frequently revealed tensions and dilemmas around universal construction of parents, which echoed the tensions within Government policies, outlined above. As we discuss below, practitioners' constructions were influenced by these dominant policy discourses as well as the culture of the setting and its priorities. Their personal experiences and perceptions of their professional roles permeate both these areas.

\section{The culture of the setting}

Practitioners made frequent references to an 'open door' policy and a 'two-way flow of information, knowledge and expertise' in line with current policy (DfEE/QCA, 2000 9). However, our observations and wider discussion based on the practitioners' individual experiences and anecdotes frequently revealed a complex picture and sometimes a 'mismatch between rhetoric, ideology and practice' (McNamara et al., 2000 474).

We're very open here. Teaching assistants greet the parents in the morning on the doors. When the doors open, the teaching assistants are there and they have paper and pencil and they take down messages and if they say 'The teacher will get back to you', we do. They can phone the school, talk to us during the day if necessary. (Teacher, Meadow School teacher)

In this school, teaching assistants took the role of gatekeepers or perhaps mediators, encouraging divisions rather than 'open doors', and we observed relationships between parents and both teaching assistants and teachers to be quite formal. The schools in our 
sample tended to have demarcated times and places when parents were allowed in and practitioners in these settings frequently talked about partnerships in terms of providing information in a transmission model (Epstein \& Saunders, 2002). Interestingly, in negotiating which practitioners should take part in the interviews and focus groups at Meadow School above, the head teacher did not put forward any teaching assistants or any roles other than teacher. This could perhaps be linked to hierarchical staffing arrangements and the perceived higher status of teachers, in line with Government policies and recent research (Sylva et al., 2004). But, if this is the case, then the practice the teacher describes above raises questions about where the setting policies position parents, how far partnership is prioritised and on whose terms. Not all the schools in our sample were quite as formal as this but it is interesting to consider the role of teaching assistants in relation to parent partnership as many were parents to children in the school, stemming from a long established tradition of parent-helpers in schools (Bach et al. 2006). Although this tradition could be considered a strategy for improving parental involvement in itself (Stobie et al. 2004), it proved problematic for the practitioners as a result of the culture of surveillance (Crozier 1998). For example a teaching assistant at Edgehill School felt it was 'easier' not to be involved with other parents in a social sense and to keep her personal life and friendships separate from her professional role because 'it gets you out of the difficult questions.'

Broadly speaking, across the schools in our sample the children's 'success' was frequently related to the rule-bound context and traditions of the school classroom (Alexander 2010) and rules were applied to relationships with parents too. For example strategies such as parent-teacher conferences were prioritised over informal communication and local policies tended to encourage a certain professional distance between teachers and parents, as indicated above. This may be related to practitioners' 
notions of professional and unprofessional behaviour in relation to parents (Dalli 2008), particularly as the emotional nature of their work with children and families is undervalued within the discourse of professionalism in England (Elfer and Dearnley 2007; Osgood 2006; Taggart 2011). Webb and Vullaimy (2002) argue that teachers are unofficially acknowledged to provide 'a culture of care' in primary schools but that there are tensions between this aspect of the role and policies that emphasise standards and pupil outcomes. Further, Urban (2008) argues that government discourses of 'quality' and 'professionalism' have merged, requiring a 'professional attitude' from teachers and other practitioners, without recognising the obscure nature of this terminology nor the complex set of challenges that they face in their relationships with children and families. This can cause dilemmas in terms of professional identity, as suggested here.

We [teachers] are like the system in a way... and I'd never really thought of myself like that before. You know I thought, 'I'm nice and I'm friendly and I welcome people in' but actually you can be all those things and still represent a kind of authority figure and it's really difficult. (Teacher, Downside School)

In comparison with the schools, the practices and models of partnership described in Children's Centre and nurseries appeared to be more flexible. This is not to say that these settings were without boundaries but the relationships appeared less formal compared to those observed in the schools, from practices such as using practitioners' forenames to the increased access that parents were given to the setting. This was in keeping with a growing amount of research based in Children's Centres that provides evidence of attempts to develop inclusive services designed to respond to specific local needs ( Bagley and Ackerley 2006; Pugh \& Duffy 2006; 2010; Robson, 2006; Whalley 2007; Williams, 2008). However, it can be argued that informal practices hide 'rules' which exclude those who are unfamiliar with the culture of the setting (Brooker, 2003). Brooker terms this 'invisible pedagogy' (2003 126) and argues that practitioners have a 
responsibility to make their own practices explicit in communication with children and parents. Certainly, many of the Children's Centres and nurseries in our sample seemed to be trying to make the invisible visible in this way, employing a variety of different strategies to communicate with parents, both formal and informal, but this was a complex undertaking. They employed transmission models (Epstein \& Saunders, 2002) to varying degrees, although only three used these as their principal approach to parent partnership in a manner similar to the schools. Epstein and Saunders also identify a 'curriculum enrichment' model (2002 413) which focuses on a two-way flow of information, incorporating knowledge from the family into the curriculum as well as encouraging families to undertake particular activities at home. Shared educational aims are the focus of the partnership in this model and, again, elements of this were apparent in the practices described by all Children's Centres and nurseries and in two of the schools. Epstein and Saunders (2002 413) also describe a 'partnership model' which is similar to Margy Whalley's 'community development approach' (Whalley, 2006 9) or the 'participatory' approach described by Pugh and Duffy (2006). Here the emphasis is on continuing dialogue and the widespread involvement of parents at different levels, for example through joint planning and shared decision-making. Participatory models of partnership were discussed as an aspiration or as a work in progress all types of setting, except one of the school settings. However, the Children's Centres in our sample appeared to be in the best position to consult with the local community in a meaningful way due to their additional role as 'service hubs' for children and families (DSCF, 2010). But questions can still be raised over which parents are taking part. Some will not participate, for example parents positioned as 'hard to reach', as we discuss below, or those with limited time or those who lack confidence or language skills. The majority of practitioners appeared to be aware of 
these challenges, demonstrated by the introduction of strategies to involve parents. For example, nurseries and Children's Centres prioritised individual relationships through the key worker system. In addition, the remit to support families weighed heavily on some Children's Centre-based practitioners, underlining the relevance of Webb and Vulliamy’s (2002 166) argument for greater recognition of practitioners' 'lived experience'. Some key workers felt they sometimes acted as unofficial counsellors and two Centre leaders expressed concerns for the emotional health of their staff in this regard. The practitioner below had described herself as a 'shrink' before discussing the impact of this aspect of her role:

\footnotetext{
It's quite hard because you've got that relationship where you are the firing line. You're very close but it's really hard because you've actually got to step away and address your concerns about that parent and sometimes ...it's hard to meet those concerns because you've got other agencies involved. It's really hard to step away...especially if you have had the child for 18 months and you've build that rapport with that parent and that child and then they come in and they are just really angry at you. (Early Years Educator, Children's Centre, inner city)
}

Webb and Vulliamy (2002) also point out that working in disadvantaged areas means that practitioners who are members of the local community may be subject to the same problems and stresses as the parents. They are referring to the primary school teacher's role but the emotional cost of partnership is echoed by Robson (2006) in her research based in complex, multi-agency early years settings.

\section{The influence of policy discourses}

Practitioners were asked to describe the families using their settings and this gave insights into the different ways that groups of parents were constructed. They generally spoke of their parent population in terms of their socio-economic status, ethnic diversity and home situation; for example whether they were working or unemployed single parents and very young parents were frequently mentioned. The dominance of particular groups varied from setting to setting and the ways that practitioners described 
these groups also varied (see table 1). Practitioners frequently used the terms 'working class' or 'middle class'. The latter group of parents were also described as 'professional' or 'affluent'. Practitioners used terms such as 'needy', 'vulnerable' or 'deprived' in relation to families with lower socio-economic status, thereby indicating practitioners' susceptibility to deficit views (Feiler et al., 2006; Whalley 2007), and in one Children's Centre some groups of parents were termed 'problem families'. The practitioners did not always appear to be aware of the political nature of their work or comments such as these (Whalley 2007). But some were struggling with these ideas and with how to improve children's lives while being non-judgemental about the lives of their parents:

\begin{abstract}
Good parents are hugely important. The bad parents are hugely important because they are educating their own children... you know it doesn't matter what we do, you know, if I'm brought up with people that think robbing tin off the roof is a good idea, I'm not going to go home and say, 'You know what mummy and daddy? I had a lesson today at school and I think maybe we ought to rethink our culture, and stop robbing tin off the roof. What do you think?' and Mummy would say 'Oh Johnny I'm so glad you said that darling.' You know, it's not going to happen. So we need to ...that's sounding so awful. I don't mean 'we' as in the practitioner, I mean 'we' as in society ... we need to work together to get that lowest common denominator, whatever it is, a bit higher. So of course it is vitally important and it's incredibly difficult, because anything worth doing well is difficult. (Deputy Head, Lowood Children's Centre)
\end{abstract}

This was just one of challenges in creating responsive, 'two-way' relationships in practice. Practitioners in all settings acknowledged that this was a complex process:

The nursery school could take over too much of "I know about your child" sort of thing and "I am the...main educator of your child," which is nonsense. I mean we do try to make the partnerships very equal by valuing what the child is doing at home and the parents' contribution into that... I guess some parents think, "Well they devalue what we do here." So again it's about communication isn't it? (Head, Emanuel Children's Centre)

However it was termed and whether practitioners were comfortable with being positioned as an 'expert' or not, discussion frequently revealed the ways that groups of parents were viewed as lacking or failing in some way, particularly lower income and ethnic minority parents. Practitioners in four of the Children's Centres employed rhetoric around 'making a difference' or 'empowering' these groups whilst others 
acknowledged the problematic nature of the constructions themselves. For example one practitioner at Northfield Children's Centre objected to the way that young parents were judged to have 'no life experience', based in part upon her own personal history as a young parent but also on her professional role and years of experience as a family support worker:

We can't all just keep saying that parents don't know because it just doesn't give credit to some parents. I hate the fact that people say 'She's a young parent, don't you know' like she's got seven heads....just because you are a young parent doesn't mean to say you need all that extra input and parenting classes because someone at 40 who has a child is as new to a situation as a 19 year old. (Family worker Northfield Children's Centre)

Another Children's Centre Head described how the perception of a Sure Start

Children's Centre as the saviour of society could be counter-productive, contrasting this with her own vision of a universally accessible setting:

There are parents from the North of the borough who can afford the bus fare to come out of their area but, knowing it's labelled 'deprived', knowing they're categorised as a particular type of parent, they don't want to be seen to be part of what is your...sort of...not traditional, that's the wrong word, but, you know, your 'Sure Start area'. "Oh you must be deprived because you're coming to that parenting group." (Head, Queens Children's Centre)

Practitioners described clear divisions between different groups of parents in another suburban setting based upon perceptions generated by these discourses of deficiency:

We have got some parents that haven't wanted to use the $3 \mathrm{~s}$ to 5 s nursery because they see it as 'council', whereas we are fee paying. So there is that divide which I think is quite sad because they could go through and see what goes on next door. (Head of Child Care, Chandlers Children's Centre)

There were other reasons that parents did not want to become involved with the setting according to the practitioners. Some of these families were labelled 'hard to reach' and this was attributed to different factors, for example cultural differences: 'the ethos of the traveller families is that children are too young to go out of the home environment at that age' (Deputy, Lowood Children's Centre). Some practitioners discussed the importance of a sensitive, responsive approach towards parents who were intimidated 
by the setting and the practitioners working there based on their own negative experiences of learning in school, recognising that working class parents may lack the confidence to engage in pedagogical discussions with practitioners (Muschamp et al., 2010). However, others saw some families as less engaged and viewed this as reluctance to support their child's learning or even apathy. But the pendulum also swung the other way and some of the more affluent parents were considered to be almost too proactive. According to Muschamp et al. (2010) middle class families are far better placed to influence their child's educational experiences and have more strategies at their disposal, particularly if they have been successful at school themselves. This can be translated into self-confidence or even a sense of entitlement (Reay, 2004). These parents were sometimes viewed as 'difficult' by the practitioners in our sample, particularly if they seemed unconvinced by the setting's approach to learning:

I mean obviously all they want is the best for their child which is obviously what we try and give. But I think some people could try and be a bit more... what can I say...I'm trying to think of a word...you know the sort of parents that come and say, 'They know how to do their ABC and they can count and they can read and...' I think that they expect so much of these three year olds. (Nursery officer, Queens Children's Centre)

Most practitioners aligned themselves with play-based learning according to their professional principles but, as was the case in the setting above, the need to accommodate different perspectives on children's learning were frequently discussed. These discussions demonstrate confusion over the conflicting messages within current policy regarding the ways that young children learn where specific learning goals and age-related developmental phases are prioritised over children's choices and play interests (DCSF, 2007b; c). Practitioners did talk of parents being convinced by playbased learning, particularly where this was one of the key messages communicated to them through the setting. However, this again has implications for the relationships as 
it places practitioners in the position of parent educators. Working with parents in this way and introducing them to the ethos and values of the setting was viewed as challenging and full of dilemmas, as is exemplified in the Centre leader's comments below. The group of parents to which she is referring had newly arrived to the country, introducing a cultural dimension to the debate. Developing partnerships with parents of a different ethnicity raises particular problems which go beyond simply not understanding the language:

Do I send out a message that says, "There's something that you've got to learn here," or do I send out a message that says, "I'd like to understand more about how you see learning." And we've actually taken that group [of parents] and we've gone through that process and what we found was that...they don't play with their children. And so we started to have a conversation about that. "That's really interesting because you know you've come into a country where people do play with their children, so how do you view play?" so starting from where those people are. And then having had that initial discussion we've shaped a family learning session... with an interpreter who actually talk about how we in this country think it's quite helpful and maybe there's some stuff here that they might find useful too. And we've actually worked through the materials with them and they've gone home with their bag of play-dough or their bag of salt or whatever it's been. (Children's Centre Head, Inner City)

The above example raises a variety of issues relating to taken-for-granted beliefs about good practice and Edwards and Warin's (1999) 'colonisation of the home' takes on a particular cultural significance here. As Brooker (2002) argues, the conviction that play-based pedagogy is universally appropriate is an ethnocentric one and, whether we like it or not, implies that cultures and education systems that differ from this produce inferior children and adults. Although the principle of play-based learning has been hard-won in the English early years curriculum in the face of more prescriptive approaches, Fleer (2003) and Brooker (2002) argue that we should continually question our inheritances. This is to ensure that there is shared construction and understanding of specialist discourse, such as 'child-centredness' and 'learning through play', so that they do not become meaningless slogans that are exclusive, particularly to 'newcomers'

(Fleer, 2003 65). 


\section{Conclusion}

The practitioners involved in our study viewed parent partnership as a fundamental aspect of 'quality' in relation to their work with children and families. Many felt that quality provision was impossible without positive relationships founded on mutual trust, shared values and a common purpose. But their comments also pointed to the complex nature of these relationships and the challenges of developing shared understandings, particularly within the framework of contradictory policy discourses. It is important to note that the revised EYFS maintains a focus on the essential role of play and characteristics of effective learning which provide a welcome emphasis on learning processes (DfE 2012a). But the non-statutory guidance retains a strong emphasis on specific outcomes and typical ranges of development (Early Education / DfE 2012). There are also requirements relating to children's stage of development in the statutory guidance as well as an emphasis on 'school readiness' here and in Coalition government policy discourses. This government has also intensified the accountability measures with a progress check for two year olds (NCB/DfE 2012) and the Year 1 Phonics Screening Check (DfE 2012b). All of which means that confusions about the priority afforded to different aspects of children's learning are likely to continue to feature in the dialogue between parents and practitioners. Having to accommodate diverse perspectives on children's learning is not a negative point per se. But practitioners need to become 'cultural brokers and mediators' in order to develop shared understandings with parents about the ways that children learn and develop (Whalley 2007: 201). This takes time and requires a high level of skill and continual professional development and therefore continued investment into the training and development of the early years workforce. Brooker (2002) argues that early years practitioners should continually re-examine their beliefs in search of an inclusive pedagogy, although this may require practitioners to question cherished terms and 
concepts. This links to the broader findings of our project and the notion that 'quality' is dynamic, elusive and contested and that positive relationships, open dialogue and critical reflection are key to developing the shared understandings which enable responsive services for children and their families (Cottle and Alexander 2011; Cottle 2011). In Brooker's view, the questioning process should be based on 'local research knowledge gained through reflective sharing' within settings as well as multiple strategies to involve parents, both on the part of the setting and the individual practitioner ( 2002 173). Vandenbroeck (2009) argues that this process requires both practitioners and parents to challenge norms and acknowledge the provisional and tentative nature of their knowledge and expertise. We found evidence of this in some of the settings we visited but the strategies practitioners employed tended to be rooted in the purposes, priorities and traditions of their setting as well as practitioners' personal and professional histories and values (Goodson, 2003). Within our sample, the schools tended to employ more formal strategies based on traditions that extended back through decades of educational policy. The Children's Centres appeared to be in the best position to develop inclusive approaches such as those advocated above due to their Government appointed remit (DfES 2003b) but this was not without emotional cost to the practitioners involved (Webb and Vulliamy 2002; Robson 2006).

Perceptions of the parents attending settings were greatly influenced by normative policy discourses which tend to position parents as either deficient or as active agents and oversimplify highly complex relationships which are imbued with issues of class and culture (Blackmore \& Hutchison, 2010). This situation raises a number of concerns. Firstly, that current systems advantage middle class parents. Secondly, that targeted intervention approaches that may be insensitive to family culture (Feiler et al., 2006) which again has connotations for both working class parents and 
ethnic minorities. Coalition Government policies seem unlikely to change this situation, considering the intention to take the Sure Start programme back to its 'original purpose'. This is defined as a 'focus on the neediest families' (HM Government, 2010) and is a move away from the comparatively social democratic orientation that was evolving from out of New Labour policies; the vision of Sure Start Children's Centres as basic provision for all children. Although the Coalition Government's vision of the 'Big Society' appears to shows some continuity with New Labour ideas of strong community and active involvement, albeit rebranded, it is underpinned by a 'responsibilisation' agenda which is attempting to shift the responsibility for a range of social problems away from the state to the individual or family or local community, making them into issues of 'self-care' (Wright 2011). This likely to impact on the poorest and least powerful in society, leaving them with little support, particularly considering the doubts about the capacity of the voluntary sector to fill the gaps left by the withdrawal of central government (Ellison 2011). In our view, this can only serve to perpetuate unequal power relationships between practitioners and parents and between different parent groups. This is likely to intensify the social stigma that some parents feel, as relayed by the practitioners in our study, and further highlight cultural, social and economic divisions (Lister 2011; Rogers 2011)

References

Alexander, Elise. 2010. A Successful Child: Early Years Practitioners' Understandings of Quality. 30 (2): 107-18.

- 2009. Understanding Quality and Success in Early Years Settings: Practitioners' Perspectives. Swindon: ESRC.

Alexander, Robin J. 2009. Children, their World, their Education: Final Report and Recommendations of the Cambridge Primary Review. London: Routledge. 
Alexander, Robin J., Christine Doddington, John Gray, Linda Hargreaves, and Ruth Kershner. 2010. The Cambridge Primary Review Research Surveys. London:

Routledge.

Bach, Stephen., Ian Kessler., and Paul Heron. 2006. Changing Job Boundaries and Workforce Reform: The Case of Teaching Assistants. Industrial Relations Journal 37 (1): 2-21.

Bagley, Carl., and Clare L. Ackerley. 2006. 'I Am Much More than just a Mum.' Social Capital, Empowerment and Sure Start. Journal of Education Policy 21 (6): 717-34.

Baldock, Peter., Damien Fitzgerald., and Janet Kay. 2009. Understanding Early Years Policy. London: Sage.

Barron, Ian., Rachel Holmes., Maggie MacLure., and Katherine Runswick-Cole. 2010. Primary Schools and Other Agencies. In eds. Robin J. Alexander, Christine Doddington, John Gray, Linda Hargreaves and Ruth Kershner The Cambridge Primary Review Research Surveys, Chapter 5. London: Routledge.

Blackmore, Jill., and Kirsten Hutchison. 2010. Ambivalent Relations: The 'Tricky Footwork' of Parental Involvement in School Communities. International Journal of Inclusive Education 14 (5): 499-515.

Brain, Kevin., and Ivan Reid. 2003. Constructing Parental Involvement in an Education Action Zone: Whose Need is it Meeting? 29 (2): 291.

Brooker, Liz. 2010. Constructing the Triangle of Care: Power and Professionalism in Practitioner/Parent Relationships. British Journal of Educational Studies 58 (2): 181-96.

2003. Learning how to Learn: Parental Ethno theories and Young Children's Preparation for School. 11 (2): 117-128.

UP.

Central Advisory Council for Education (England)., Bridget Horatia Plowden Baroness., and Great Britain. Department of Education and Science. 1967. Children and their Primary Schools: A Report of the Central Advisory Council for Education (England). London: H.M.S.O.

Cottle, Michelle. 2011. Understanding and Achieving Quality in Sure Start Children's Centres: Practitioners' Perspectives. International Journal of Early Years Education 19 (3-4): 249-65.

Cottle, Michelle., and Elise Alexander. 2012. Quality in Early Years Settings: Government, Research and Practitioners' Perspectives. British Educational Research Journal 38 (4): 635-654.

Crozier, Gill. 2000. Parents and Schools: Partners or Protagonists? Stoke on Trent: Trentham Books. 
1998. Parents and Schools: Partnership Or Surveillance? Journal of Education Policy 13 (1): 125-36.

Crozier, Gill., and Diane Reay. 2005. Activating Participation: Parents and Teachers Working Towards Partnership. Stoke-on-Trent, UK; Sterling, VA: Trentham Books.

Dalli, Carmen. 2008. Pedagogy, Knowledge and Collaboration: Towards a Ground-• up Perspective on Professionalism. European Early Childhood Education Research Journal 16 (2): 171-85.

Department for Children Schools and Families (DCSF). 2007a. Early Years Foundation Stage: Setting the Standards for Learning, Development and Care for Children from Birth to Five. Nottingham: Department for Children Schools and Families.

- 2007b. Practice Guidance for the Early Years Foundation Stage: Setting the Standards for Learning, Development and Care for Children from Birth to Five. Nottingham: Department for Children Schools and Families.

- 2007c. Statutory Framework for the Early Years Foundation Stage: Setting the Standards for Learning, Development and Care for Children from Birth to Five. Nottingham: Department for Children Schools and Families.

2010. - Sure Start Children's Centres in United Kingdom Department for Children, Schools and Families [database online]. Available from http://www.surestart.gov.uk/London, 2010 [accessed January 19 2010].

Department for Education (DfE). 2012a. Statutory Framework for the Early Years Foundation Stage: Setting the Standards for Learning, Development and Care for Children from Birth to Five. London: Department for Education.

2012b. Year 1 Phonics Screening Check: Assessment and Reporting Arrangements. London: Department for Education.

Department for Education and Employment (DfEE). 1998. Meeting the Childcare Challenge. London: HMSO.

1997. Excellence in Schools. London: HMSO.

Department for Education and Employment (DfEE) /Qualifications and Curriculum Authority (QCA). 2000. Curriculum Guidance for the Foundation Stage. London: Department for Education and Employment and Qualifications and Curriculum Authority.

Department for Education and Skills (DfES). 2007. Every Parent Matters. London: Department for Education and Skills.

_. 2003a. Every Child Matters. London: Department for Education and Skills. 2003b. Sure Start Guidance 2004 - 2006: Overview and Local Delivery Arrangements. London: Department for Education and Skills. 
2002. Birth to Three Matters: A Framework for Supporting Children in their Earliest Years. London: Department for Education and Skills.

Desforges, Charles., and Alberto Abouchaar. 2003. The Impact of Parental Involvement, Parental Support and Family Education on Pupil Achievements and Adjustment: A Literature Review. London: DfES.

Early Education / Department for Education (DfE). 2012. Development Matters in the Early Years Foundation Stage. London: British Association for Early Childhood Education / Department for Education.

Edwards, Anne., and Jo Warin. 1999. Parental Involvement in Raising the Achievement of Primary School Pupils: Why Bother? 25 (3): 325.

Elfer, Peter., and Katy Dearnley. 2007. Nurseries and Emotional wellbeing: Evaluating an Emotionally Containing Model of Professional Development. Early Years 27 (3): 267-79.

Ellison, Nick. 2011. The Conservative Party and the 'Big Society'. In eds. Christopher Holden, Majella Kilkey and Gaby Ramia. Social policy review 23, 45-62. Bristol: Policy Press.

Epstein, J. L., and M. G. Saunders. 2002. Family, School and Community Partnerships. In, ed. M. Bornstein Handbook of Parenting Vol 5: practical issues in parenting. London: Lawrence Erlbaum Associates.

Eurydice Report. 2009. Early Childhood Education and Care in Europe: Tacking Social and Cultural Inequalities. Brussels: Education, Audiovisual and Culture Executive Agency.

Feiler, Anthony., Pamela Greenhough., Jan Winter., Leida Salway., and Mary Scanlan. 2006. Getting Engaged: Possibilities and Problems for Home-School Knowledge Exchange. 58 (4): 451-69.

Fitzgerald, Damien. 2004. Parent Partnership in the Early Years. London: Continuum.

Fleer, Marilyn. 2003. Early Childhood Education as an Evolving 'Community of Practice' Or as Lived 'Social Reproduction': Researching the 'Taken-for-Granted'. 4 (1): 64-79.

Gewirtz, Sharon. 2000. Bringing the Politics Back in: A Critical Analysis of Quality Discourses in Education. 48 (4): 352.

Goodson, I. 2003. Professional Knowledge, Professional Lives: Studies in Education and Change. Maidenhead: Open University Press.

Hallgarten, Joe. 2000. Parents Exist, Ok!? : Issues and Visions for Parent-School Relationships. London: IPPR. 
Hammersley, Martyn., and Paul Atkinson. 2007. Ethnography: Principles in Practice. London: Routledge.

2010. HM Government. The coalition: our programme for government in Cabinet Office [database online]. Available from http://programmeforgovernment.hmg.gov.uk London, 2010 [accessed May 26 2010].

HM Treasury. 2004. Choice for Parents, the Best Start for Children: A Ten Year Strategy for Childcare. London: HMSO publications.

Hohmann (formerly Gelder), Ulrike. 2007. Rights, Expertise and Negotiations in Care and Education. Early Years 27 (1): 33-46.

Holden, Christopher., Majella Kilkey., Gaby Ramia., and Social Policy Association (Great Britain), eds. 2011. Social policy review 23. Bristol: Policy Press.

Hujala, Eeva., Leena Turja., Maria Filomena Gaspar., Marika Veisson., and Manjula Waniganayake. 2009. Perspectives of Early Childhood Teachers on parent-teacher Partnerships in Five European Countries. European Early Childhood Education Research Journal 17 (1): 57-76.

Isaacs, Susan. 1932. The Children we Teach. London: University of London Press Ltd.

Lister, Ruth. 2011. The Age of Responsibility: Social Policy and Citizenship in the Early $21^{\text {St }}$ Century. In eds. Christopher Holden, Majella Kilkey and Gaby Ramia Social policy review 23, 63-84. Bristol: Policy Press.

MacLure, Margaret. 2003. Discourse in Educational and Social Research. Buckingham; Philadelphia, PA: Open University.

McNamara, Olwen., David Hustler., Ian Stronach., Marta Rodrigo., Emma Beresford., and Sue Botcherby. 2000. Room to Manoeuvre: Mobilising the 'Active Partner' in Home-School Relations. 26 (4): 473.

Miles, Matthew B., and A. M. Huberman. 1994. Qualitative Data Analysis: An Expanded Sourcebook. London: Sage.

Moss, Peter. 2004. The Early Childhood Workforce in 'Developed' Countries: Basic Structures and Education UNESCO Policy Brief on Early Childhood No 27United Nations Educational Scientific and Cultural Organisation.

Muschamp, Yolande., Felicity Wikeley., Tess Ridge., and Maria Balarin. 2010. Parenting, Caring and Educating. In eds. Robin J. Alexander, Christine Doddington, John Gray, Linda Hargreaves and Ruth Kershner The Cambridge Primary Review Research Surveys, Chapter 4. London: Routledge.

NCB / DfE. 2012. A Know how Guide: The EYFS Progress Check at Age Two. London: National Children's Bureau supported by Department for Education. 
Osgood, Jayne. 2006. Deconstructing Professionalism in Early Childhood Education: Resisting the Regulatory Gaze. 7 (1): 5-14.

Pugh, Gillian. 2010. The Policy Agenda for Early Childhood Services. In, eds. Gillian Pugh, Bernadette Duffy Contemporary issues in the early years, 7-20. London: SAGE.

Pugh, Gillian., and Bernadette Duffy. 2006. Contemporary Issues in the Early Years. London: SAGE.

Reay, Diane. 2004. Education and Cultural Capital: The Implications of Changing Trends in Education Policies. 13 (2): 73-86.

Robson, Sue. 2006. Parent Perspectives on Services and Relationships in Two English Early Years Centres. Early Childhood Development and Care 176 (5): 443-60.

Rogers, Chrissie. 2011. Mothering and Intellectual Disability: Partnership Rhetoric? British Journal of Sociology of Education 32 (4): 563-81.

Rumbold, Angela., Great Britain. Department of Education and Science and Great Britain Committee of Inquiry into the Quality of Educational Experience offered to 3and 4-year olds. 1990. Starting with Quality: The Report to the Department of Education and Science of the Committee of Inquiry into the Quality of Educational Experience Offered to 3-and 4-Year-Olds. London: HMSO.

Schwandt, T. 1998. Constructivist, Interpretivist Approaches to Human Enquiry. In eds. N. K. Denzin, Y. S. Lincoln The Landscape of Qualitative Research: theories and issues. Thousand Oaks, CA: Sage.

Smidt, Sandra. 2007. A Guide to Early Years Practice. 3rd ed. London: Routledge.

Steedman, Carolyn. 1990. Childhood, Culture and Class in Britain: Margaret McMillan, 1860-1931. London: Virago.

Stobie, Ingeborg., Jim Boyle., Lisa Woolfson., Emma Truswell., and Noreen Connaughton. 2004. Quality Indicators for Effective Early Intervention in Literacy and Numeracy. International Journal of Early Years Education 12 (2): 157-68.

Sylva, Kathy., Edward Melhuish., Pam Sammons., Iram Siraj-Blatchford., and Brenda Taggart. 2004. The Effective Provision of Pre-School Education (EPPE) Project:

Findings from Pre-School to End of Key Stage 1. London: Sure Start.

Taggart, Geoff. 2011. Don't we Care? The Ethics and Emotional Labour of Early Years Professionalism. 31 (1): 85-95.

Tanner, Emily., Elaine Welsh., and Jane Lewis. 2006. The Quality-Defining Process in Early Years Services: A Case Study. 20 (1): 4-16.

Tizard, Barbara., and Martin Hughes. 1984. Young Children Learning. Cambridge, Mass.: Harvard University Press. 
Urban, Mathias. 2008. Dealing with Uncertainty: Challenges and Possibilities for the Early Childhood Profession. European Early Childhood Education Research Journal 16 (2): 135-52.

Vandenbroeck, Michel. 2009. Let Us Disagree. European Early Childhood Education Research Journal 17 (2): 165-70.

Webb, Rosemary., and Graham Vulliamy. 2002. The Social Work Dimension of the Primary Teacher's Role. Research Papers in Education 17 (2): 165-84.

Whalley, Margy. 2007. Involving Parents in their Children's Learning. London: Paul Chapman.

. 2006. Children's Centres: The New Frontier for the Welfare State and the Education System? Grand Hotel, Oslo, Norway.

Whalley, Margy., and Pen Green Centre Team. 1997. Working with Parents. London: Hodder \& Stoughton.

Williams, Fiona. 2008. Empowering Parents. In eds. Angela Anning, Mog Ball Improving services for young children : from Sure Start to children's centres, 62. London: SAGE.

Wright, Adam. 2011. Fantasies of Empowerment: Mapping Neoliberal Discourse in the Coalition Government's Schools Policy. Journal of Education Policy: 1-16. 